\title{
MOTIVATION, ATTITUDE, NEED, AND EVALUATION OF THE STUDENTS OF IAIN MATARAM IN LEARNING ENGLISH AS A GENERAL SUBJECT TO DEAL WITH GLOBALIZATION ERA
}

\author{
Ribahan \\ Institut Agama Islam Negeri (IAIN) Mataram \\ e-mail: Ribhansyah@yahoo.co.id
}

\begin{abstract}
This study aims at investigating motivation, attitude, needs, and evaluation of the students of IAIN Mataram in learning English as a general subject. The data were gathered from questionnaire and they were presented descriptively. The result of questionnaire showed that the students considered English very important (98\%). The motivation of the students in learning English was very high (93\%) and they learned English for intrinsic reasons (77\%). The attitude of the students in learning English was very positive (84\%). The students preferred learning English visually to learning orally $(81 \%)$. The teacher taught seriously $(95 \%)$, the teacher gave various tasks $((91 \%)$, and the teacher gave motivation to the students (95\%). The class size supported the teaching and learning process (99\%). The students competed seriously in learning English (77\%). The students needed English relevant to their content subject $(90 \%)$ and they needed more reading skill than the three other skills (83\%).
\end{abstract}

Keywords : motivation, attitude, needs, evaluation, English

\section{INTRODUCTION}

It is undeniable that English is a global language in which more than 60 countries use English as the official language today (Crystal, 1996: 106). English has been able to show its existence as an international language which spreads almost all over the world and it has a very important role in various aspects of life. As a consequence, English promises a lot of benefits; economically, politically, socially, and culturally, as well as influences other fields such as science, technology, and information. This role can not be separated from the United States and Britain as the users of English and the super power countries which can show their influence to the the world and create dependence, without exception, in the field of language. A number of scientific forums are organized by inviting speakers from abroad, such as America, Singapore, Australia who use English as a main language.

Today English has become a language of education, business, government and other social situations. Many science and technology books are published in English. In addition, a lot of business transactions and international diplomacy are performed in English; therefore, whether you like or not, you should be able to master it both oral and written. State leaders, diplomats, negotiators, entrepreneurs, teachers, lecturers, and students are of course demanded to speak English, depending on their interests, roles, duties, and responsibilities. Moreover, English has developed from year to year and it's role is so important to learn many things, especially at the university level which highly depends on English textbooks. Thus, mastering English language becomes a necessity for students to broaden their scientific horizon.

In academic context, the main reason for students in university to learn English is to help them acquire information in their field of study through textbooks, articles, lecture notes, technical instructions and others. According to Harmer (1998), Many students want to be able Lingua Scientia| 79 
to read texts in English either for their careers, for study purposes or simply for pleasures (Harmer, 1998).

The mastery of English is a strategic way to enter into global era i.e. the era of openness in which the quality and the skill of using English, written or spoken, are required in order to be able to professionally compete with other developed countries, especially in the process of transferring knowledge and technology. For those who have mastered English, becoming involved in the global era in which the association with foreign countries cannot be avoided, is not problem anymore. With the English ability they have, of course, they can access information easily, they can make certain relationships easily and the most important is they can communicate easily with those who use English as a means of communication.

Recognizing the importance of English globally and acdemically, IAIN Mataram as an Islamic higher education institution which develops and integrates aspects of Islam and science, expects their students to be able to communicate in English with other people, both at national and international level (Education Handbook of IAIN Mataram, 2005). English becomes very important for people who live in the globalization era like today, with no exception, in the field of academic, which requires both lecturers and students to read various English literatures to absorb information in the process of transfering knowledge.

In 1994 curriculum of IAIN Mataram, it is clearly stated that English is one of the foreign languages taught to students, besides Arabic to fulfill the expectations of the institution. The existence of language centre unit and extracurricular organizations which hold English courses is a form of institutional support in order to develop the English ability of the students and lecturers. Furthermore, the purpose of English language teaching and learning at IAIN Mataram is to enable the students to communicate in English both oral and written. The total credit allocated for English course at IAIN Mataram is 8. The students learn English in various levels, namely
English Matriculation 1, 2, and English 1, 2. This is of course intended to provide greater cahances for the students to master English.

Based on what has been elaborated above, this study is intended to find out: (1) the students' level of motivation in learning English, (2) the motivation of students in learning English, (3) the students' attitude in learning English, (4) aspects of English required by the students, and (5) the students' evaluation toward ongoing programs. The results of this study are expected to contribute to the teaching of English at IAIN Mataram, especially in in planning, implementing, and preparing English language teaching programs at IAIN mataram.

The Teaching of English IAIN Mataram

The main goal of teaching English at IAIN Mataram is to develop english skills of thge students so that they will able to understand English literatures such as textbooks, journals, magazines, newspapers and other sources (Curriculum of IAIN Mataram, 1994). The total credit offered to the students is 8 . As a general subject, the students learn English in various level, namely English Matriculation 1, 2 and English 1, 2, each has 2 credits. This is intended to give students greater opportunity to learn English at IAIN Mataram.

The students of IAIN Mataram have diverse backgrounds and academic abilities which affect their English skills. They are generally graduates of Islamic Senior High School and General Senior High School with different learning situation and circumtances.

\section{MOTIVATION}

A foreign language learner (English) usually has a certain motivation and takes various ways to achieve what he/she wants. Brown (200 1:72) suggests that motivation is a decision about goals accompanied by an attempt to achieve them. Meanwhile Ur (1996: 273) is not interested in defining motivation, because it is perceived as a difficult concept, so he prefers to talk about 'motivated learners'.

The goals such as pursuing a particular career, being able to communicate with strangers, continuing education abroad, gaining certain prestige, recognizing the native speakers' cultures of the language learned are some of Lingua Scientia| 81 
the motivation in learning a second language. The intensity of the learner's motivation about the goals she/he wants to achieve is different, it can be high, or may be low, depending on the orientation of the learners themselves.

\section{THE IMPORTANCE OF MOTIVATION}

Motivation is an important factor in learning foreign languages including English. According to Gardner (1974), in learning a language, motivation is more important than intelligence and talent for a beginner and it becomes a positive determinant for the success of learning. Regarding with this, Naiman at all (1978) states that the success of a learner is not only determined by the easyness of what she/he learns, but it also depends on the strength of motivation she/he has. In relation to this, it can be said that the learners who have a strong motivation tend to be more successful than those who have a weak motivation.

Because of the importance of motivation in determining the success of language learning, certain strategies are required to achieve the learning goals and it should become a priority to support the success of learning activities in the classroom. Motivation is also closely related to the achievements of the learners in language learning. This is supported by several research findings such as those conducted by Gardner and lambert (1972) and Gardne (1980).

\section{INTRINSIC AND EXTRINSIC MOTIVATION}

People learn a foreign language for certain reason or motivation. There are two kinds of motivation which affect the success of learners in their learning activities, namely intrinsic and extrinsic morivationb. According to Ur (1996: 276), intrinsic motivation is the insistence which causes the learners to engage in learning activities for the interest of learning itself. This kind of motivation can be in the form of self-actualization, certain status, symbol of identity and so forth. It also has the power to nurture one's curiosity, develop one's competence and maintain one's stability in developing self-confidence. On the other hand, extrinsic motivation is the one which derives from external factors, such as curriculum, cempetition, community, expectation, and so on.

\section{ATTITUDE}

Another factor which affects the results of language learning is attitude. Learner's motivation can be observed from the attitude toward the language he/she is learning. In other words, whether a learner has a low or high motivation, it is determined by his/her attitude. According to Gagne (1985: 219), attitude is the internal state of the learners which influences the choice of possible actions. Beside that, attitude affects the outcomes of language learning (Gardner, 1973). In attitude, there is a readiness and individual response to the object or situation where the individual involved in it.

\section{COMPONENTS OF ATTITUDE}

Historically, attitude is a basic study of social psychology. Attitude refers to intellectual abilities and motor skills which influences an individual's choice of actions in responding to a certain situation or object. One of the components of attitude according to Travens (1982: 376) is "affective." This component serves as a basis for the investigation of the students' attitude toward English as a general subject at IAIN Mataram.

Affective has to do with the emotions and feelings. In this case, attitude may be positive or negative and may vary, depending on the situation or object in which it is confronted. One of the important dimensions of "affective" is the feeling of 'likes' and 'dislikes.' A person who has a positive attitude can mean that he likes something. On the other hand, someone who has a negative attitude can mean that he dislike something.

\section{NEED ANALYSIS}

The success of learning and teaching activities is usually associated with the learner's needs. It is expected that by taking the needs of the learner into account, the learners become more motivated and they will be able to meet their learning needs and characteristics. Every learner has a different need in learning English and he/she should learn what he/she needs. 
Therefore, identification of the learner's needs in learning English should be done to meet the needs and scientific background of the learner. According to Richard (2001), the procedure used to collect information about the needs of a learner is called 'needs analysis'. Furthermore, Hutchinson and Waters (1991) suggests that engaging learners in exploring their needs is a common practice. Learners are active participants in teaching and learning activities and the centre of learning, so that they can be asked about the ideal methods to be be applied in the classroom. In relation to this, Dick and Carey (1985: 15) states the center of the whole learning process is the learners. Collecting information directly from the learners about their needs and setting them as the goal of learning is very important.

\section{ENGLISH FOR SPESIFIC PURPOSES (ESP)}

Needs analysis is closely related to English for a specific purpose which is better known as ESP. The assumption underlying this approach is the clear relevance of the English learned to the needs of the learners. It is expected that by fulfilling the needs of the learners, the motivation of the learners can be increased and the learning process becomes faster and better. English language has developed rapidly and it has opened up great opportunities for both teachers and researchers as new domain of profession (Or, 2002: 1).

Hutchinson and Waters (1991) divides ESP into two main branches: English for Academic Purposes (EAP) and English for occupational Purposes (EOP). Then, as the industry is growing up rapidly, English for other special purposes comes with different names such as English for Business Purposes (EBP), English for Educational Purposes (EEP), English for recreational purposes and others.

\section{THE STUDENTS EVALUATION OF ONGOING PROGRAMS}

As active participants in teaching and learning activities, learners can be served as a useful resource to obtain information about teaching and learning activities which are appropriate and suitable in the classroom. This step is a series of second language learning activities (Wenden, 1986). The evaluation expected from the students in this study is the evaluation of ongoing programs, teachinglearning activities, media, lecturers, social environment, tasks, and the clarity of the learning materials presented. The result is expected to be an input to the ongoing programs and it can provides solution to the existing problem

\section{METHOD}

Because this study was intended to find information about the motivation, attitude, needs, and evaluation of students of IAIN Mataram in studying English as a general subject, the design used in this study was of descriptive. According to Furchan (1982: 415), a descriptive study is designed to obtain information about the status of symptoms at the time of the study. This kind of study has the purpose of determining the nature of a situation at the time of the investigation. Furthermore, Ibnu et al. (2003: 46) explains that a descriptive study aims to describe the important events which happen today. The description is presented systematically and it emphasizes factual data rather than inferences.

The subjects of this study was the second year students of IAIN Mataram, in this case, there were 59 students involved in this study. A questionnaire containing 35 questions and designed according to the Likert scale was distributed and filled in by the students to collect data on the students' motivation, attitude, needs, and evaluation in learning English. The options for answer on the scale ranging from $0 \%$ to $100 \%$ agree. Then, the data was analyzed descriptively. The average percentage of the students' agreement on the statements in the questionnaire were the answers to the questions in this study, namely the strength of motivation, the type of motivation, the nature of attitude, the needs, and the evaluation of the students. 


\section{RESULTS AND DISCUSSION}

\section{THE STRENGTH OF MOTIVATION}

The data showed that the students of IAIN Mataram considered English as a general subject very important. The students who agreed on this statement were $98 \%$. There were only $2 \%$ of the students who considered English as a general subject not important. In relation to this finding, there should be continuous efforts to improve the quality of English language teaching and learning at IAIN Mataram, both in terms of materials, methods, strategies, and others. It was also known that the students had a very high motivation towards English as a general subject. The strength of their motivation was supported by the fact that a. $94 \%$ of the students really learned English and they did not want to miss every session, b. $96 \%$ of students learned English seriously, c. $91 \%$ of the students learned English to get a good job, and d. $89 \%$ of the students were confident to be successful in learning English. The strength of their motivation in learning English is 93\%.

\section{TYPE OF MOTIVATION}

The data showed that many students had intrinsic motivation in learning English. The percentage of their agreements to this variable was $77 \%$. This finding could also be viewed from the average percentage of learning subvariables obtained such as a. means of learning other knowledge (89\%), b. building confidence $(97 \%)$, c. widening knowledge $(85 \%)$, and $d$. gaining additional competencies (92\%). The strength of the students' intrinsic motivation in learning English was 91\%. Only 13\% of the students has extrinsic motivation in learning English, namely to meet the demand of credit.

\section{ATTITUDE}

The students' attitude towards English as a general subject was very positive. The data obtained pertaining to each sub-variable of the students' attitude supported this finding, namely a. English is important for entering the workforce (97\%), b. English is important for continuing study (88\%), c. English needs to be mastered by the all educated (83\%), d. English is often required in everyday life (79\%), and e. English is used to assess personal proficiency (71\%). The average percentage of the students' agreement was $84 \%$. In respect to the goals of learning English, entering the workforce and continuing study obtained very high percetage.

\section{LEARNING STYLE}

The data obtained related to learning style of the students showed that the students could learn English better visually (91\%) than orally $(76 \%)$, because they could learn better when they had notes and written exercises $(81 \%)$ than that of when they dealt with oral tasks (72\%). It was also found that $78 \%$ of the students agreed on the lecturers who provided written explanations based on needs and there were $67 \%$ of the students who agreed on the lectures who gave written exercises. The students also stated that the lecturers were quite serious in giving explanations (95\%) and they gave enough encouragement to the students (70\%).

\section{CLASSROOM ATMOSPHERE}

The data revealed that classroom atmosphere could encourage the students to learn English. This finding was supported by the students' disagreement on the statement that many students in the classroom studied seriously (99\%). This was so far in line with the fact that the number of the students in each class were 15-20 at IAIN Mataram, which enabled them to learn more quietly and more seriously than that of when the class were full of students. It was also known that the seriousness of the students in learning English obtained high percentage (77\%). This simply means that the students had a strong and serious motivation in learning English.

\section{ASSIGNMENTS}

The data indicated that the assignments given by the lectures in the classroom were few (43\%) and there were many students who agreed on the statement that the assignments given were quite various and interesting (91\%). 


\section{NEEDS}

The data showed that the students who needed general English are only 32\%. Most of them needed English related to their content subject $(90 \%)$. It was also found that reading skills were more needed than other skills (83\%), such as speaking $(75 \%)$, listening $(72 \%)$, and writing (69\%).

\section{CONCLUSION AND SUGGESTIONS}

It can be concluded that English as a general subject at IAIN Mataram is still very important for the students. The high motivation and positive attitude of the students towards English as a general subject support this conclusion. Regarding with teaching and learning activities, the students tend to choose visual learning style and they feel that the existing classroom atmosphere is very conducive for teaching and learning activities. They also think that lecturers teach seriously and give enough and various assignments and the students compete to be successful in learning English.

The quality of English language teaching and learning at IAIN Mataram needs to be improved in order that the English proficiency of the students can be enhanced. The lecturers are expected to be able to plan and implement appropriate English programs for the students of IAIN Mataram, namely a good preparation of materials, methods, strategies, and others. For institution, the results of this study can be served as the basis for planning and designing more concrete programs related to the English language teaching management at IAIN Mataram.

\section{REFERENCES}

Ary, D.J., Lucy, C., and Razavieh, A. Pengantar Penelitian Pendidikan. Terjemahan Oleh Arief Furchan. (1982). Surabaya: Usaha Nasional.

Brown, D.H. (2001). Teaching by Principle: An Interactive Approach to Language Pedagogy ( $2^{\text {nd }} E d$.). New York: Addison Wesley Longman, Inc.
Buku Pedoman Penyelenggaraan Pendidikan IAIN Mataram. (2005).

Crystal David. (1999). The Cambridge Encyclopedia of the English Language. Cambridge University.

Dick, W and Carey, L. (1990). The systematic Design of Instruction. USA: Harper Collins Publishers.

Gardner, R.C. and Lambert, W.R. (1972). Attitudes and Motivation in Second Language Learning. Rowley Mass: Newbury House Publishers.

Gardner, R.C. (1974). Motivational Variables in Second Language Learning. Proceedings of the Fifth Symposium of the Canadian Association of Applied Linguistics, 45-73.

Garner, R.C. (1980). On the Validity of Affective Variables in Second Language Acquisition: Convceptual, Contextual, and Statistical Consideration, Language Learning, 30, 255-70.

Gagne, Robert M. (1985). The Condition of Learning and Theory of Instruction ( $4^{\text {th }}$ Ed.). CBS College Publishers.

Hutchinson, Tom, and waters, Alan, (1991). English for Specific Purposes: A LearningCentered Approach. Cambridge: Cambridge University Press.

Harmer, Jeremy. (1998). How to Teach English: An Introduction to the Practice of English Language Teaching. Addison Wesley Longman Limited.

Naiman, 1978. The Good Language Learners. Research in Education Series, No 7, Toronto: Ontario Institute for Studies in Education.

Orr, Thomas (Ed.). (2002). English for Specific Purposes. Virginia: Teacher of English to Speakers of other Language, Inc.

Richard, J.C. (2001). The Language Teaching Matrix. Cambridge: Cambridge University Press. 
Suhadi, Ibnu dkk. (2003). Dasar-Dasar Metodologi Penelitian. Universitas Negeri Malang.
Travers, Robert, MW. (1982). Essentials of Learning: the New Cognitive Learning for Students of Education. Macmillan Publishing Co. Inc.

Ur, P. (1996). A course in Language Teaching. Practice and Theory Cambridge: Cambridge 